\title{
CHILEAN TRANSLATIONS OF SHAKESPEARE: DO THEY CONSTITUTE A NATIONAL SHAKESPEARE CANON?
}

\section{Paula Baldwin Lind}

\section{Preliminary Concepts: Defining the Shakespeare Canon}

When John Heminge and Henry Condell published Shakespeare's works, in a certain way - perhaps without knowing - they established the Shakespeare Canon, as they listed what they thought were Shakespeare's true original copies. In spite of the fact that textual studies have demonstrated that some of these plays were written in coauthorship with other playwrights from the period, and that there is no evidence to prove that the copies the publishers used were manuscripts from Shakespeare, the result was the publication of the First Folio of 1623: Mr. William Shakespeare's Comedies, Histories \& Tragedies. Moreover, foundational bibliographical studies by W.W.Greg (1955), Charlton Hinman (1963), and A.W.Pollard (1909) point out that, even though at least twenty-two of the plays had been published in Quarto format, a folio devoted entirely to plays was unprecedented before this publication. Thus, we could say that it became a revolutionary printing endeavour that made available most of the author's works for the first time in one volume (Jowett, 2007). Shakespeare's contemporaries, Elizabethan theatregoers, and courtiers might have known a number of plays because they had seen them performed at The Globe, The Blackfriars, or at Court, yet possibly they found only some of them in print.

It is quite problematic to state that Shakespeare wrote his plays only to be performed. Even though he was not directly involved in the publication of most of them, we cannot state that he did not want to see his plays printed. According to John Jowett (2007, p. 9-10), the economic interest of the theatre very often determined the timing of publication which was usually several years after playwrights had finishing writing a play. Furthermore, Lukas Erne (2003, p. 56) adds that "Shakespeare was a writer of plays that could be read in print as well as witnessed on stage." Performance and publication were not mutually exclusive options for theatre companies who "viewed two of a play's forms of publication - performance and print, the stage and the page, the playhouse and the printing house — not only compatible but synergetic" (p. 90). 
Seven years after Shakespeare had died, the Folio publishers commissioned the professional scribe Ralph Crane to prepare transcripts of the supposedly original manuscripts to be used as printer's copy for at least The Tempest, The Two Gentlemen of Verona, The Merry Wives of Windsor, Measure for Measure, The Winter's Tale, and possibly Cymbeline (Rasmussen 2001, p. 145-47). For the other plays, the Folio compositors had access to a wide variety of copies: "good" and "bad" Quartos, playbooks, and even transcripts made by unidentified scribes or actors. Consequently, we cannot state that the Folio is Shakespeare, not only because of the origin of the copies, but mainly because of the long process - not exempt from typing mistakes, misspellings, technical errors, ink blots, among many other "accidents" - that these works went through before being printed.

The fact is that despite the First Folio's shortcomings, Shakespeare's works were published in 1623, shortly after Blount and Jaggard entered the final copy of the plays in the Stationers' Register. A copy was sent for binding on 17 February 1624 to the Bodleian Library in Oxford and the book was then available in bookshops for the sum of $£ 1$ (Rasmussen 2001, p. 145-47). These events briefly summarise the origin of the Shakespeare canon: a list of works that was arbitrarily selected by two actors, certainly not guided by the playwright's criteria, but more likely by external factors such as the copies available during that period and, why not, Heminge's and Condell's admiration for master Will.

The history of the Folio raises a number of interesting questions: has the Shakespeare canon remained stable? Does it mean the same in the playwright's homeland than in other countries? How do translation, printing and publication policies might define this canon? In the following sections of this paper we will examine how the Shakespeare canon might be configured outside Britain, taking examples from translations done in Chile or by Chileans, and using The Tempest, translated in September 2010, as a study case.

\section{Brief review of Shakespeare translations in Chile, or by Chileans}

Even though the concept of "canonical" has become quite controversial in the past years, there is no doubt that Shakespeare and his canon have become central in the English-speaking world. When Harold Bloom published The Western Canon in 1994, his polemical judgement that "Shakespeare is the Western Canon" (1994, p.76), 
provided critics all over the world with material to discuss about the nature of the literary canon. A religious word in its origin, the canon has frequently become equivalent to a choice or list of books for required study. Nevertheless, according to Bloom, this choice would not be arbitrary if critics take into account elements such as: aesthetic value, cognitive acuity, linguistic energy, and power of invention of each work; yet, when asked what he considers "the" element that makes an author and his works canonical, Bloom states that it is "[...] strangeness, a mode of originality that either cannot be assimilated, or that it assimilates us that we cease to see it as strange" (1994, p. 2). Evidently, his theory about the canon is rather arguable if we think that most of the concepts he uses, to decide whether a book is canonical or not, are very difficult to determine. In addition to this, most critics claim that his idea of the canon is elitist and narrow since he chooses only twenty-six authors from all the novelists, playwrights and poets of the whole world. We do not intend to solve this debate here, but to analyse and try to understand the reasons for Shakespeare's survival within the canon outside Britain. In this sense, Bloom's argument that Shakespeare has become universal as he is acted and read everywhere, in every language and circumstance, is not distant from reality; on the contrary, it contributes to the argument that the Shakespeare canon is no longer circumscribed to the British isles, yet has become, at the same time, global in its scope and very idiosyncratic in the many countries where he is translated, published, read, and staged.

In 2010 the first Chilean translation of The Tempest was published by Editorial Universitaria - one of the most prestigious academic publishers in the country - with a print run of 1000 copies, thus adding to the Chilean canon a new play. Intended for teaching at high school and university level, as well as for performance, the book is part of the collection "The World of Letters" which includes poetry anthologies from Chilean authors like Pablo Neruda, and Gabriela Mistral (both Nobel prizes), but also from the English Robert Browning, the Spanish Jorge Manrique, and the Czech R. M. Rilke; Chilean and Spanish narrative works by M. Luisa Bombal, Alberto Blest Gana, and Miguel de Unamuno respectively; universal authors like Thomas Mann, Guy de Maupassant, and R. L. Stevenson; and finally, theatre from the Spanish Golden Age Lope de Vega, De Molina - in addition to Shakespeare's Spanish contemporary, Miguel de Cervantes. The list of works in this collection is undoubtedly quite heterogeneous in literary movement or period; however, these authors could be considered canonical both because of their aesthetic quality (although I believe some of them are not comparable), 
and also - in Bloom's words - due to their 'strangeness', that capacity of surprising us no matter the moment when we read them.

Editorial Universitaria is practically the only national publisher that has systematically printed Shakespeare translations, each with a considerable number of editions. The Tempest is only one example of the works Universitaria has published, thus becoming part of what we might call the Chilean Shakespeare canon. However, which plays are included in this category? Why? What are the criteria behind this selection?

The list of Chilean translations is long and deserves analysis. Fourteen plays by Shakespeare - six comedies, five tragedies, two histories, and one romance - have been translated in Chile or by Chileans from 1944 to 2010. A Midsummer Night's Dream was translated by Oscar Stuardo and published by the Theatre School from the University of Chile in 1979; then Editorial Universitaria published Juan Cariola's volume including three comedies: The Merchant of Venice, A Midsummer Night's Dream, and As You Like It in 1981. His translations are written in prose, have got notes at the end of each play and include some illustrations. Another comedy that was translated in 1981 by Cariola, once again as part of a volume, is As You Like It. As in the case of the previous play, the prose edition has got a few notes at the end of each play and some illustrations (See Cariola, 1981). Following the list of comedies, Pedro Ortus and Jaime Silva translated The Comedy of Errors in 1967 which was published by the Theatre School from the University of Chile with the purpose of being performed (Orthous \& Silva 1967). Although sometimes labelled as a problem play ${ }^{1}$ because of its ambiguous tone and the combination of comic, tragic, and romantic elements, The Merchant of Venice has been translated in the country twice: in 1978 by Hernán Letelier, also published by the University of Chile, and in 1981 with two other comedies by Cariola, whose individual publication of the same play by Editorial Universitaria in 1982 has reached its second edition. ${ }^{2}$ Most of the translations done for the Theatre School at the University of Chile were intended for performance. In addition to the comedies aforementioned, there are also two publications of The Merry Wives of Windsor: one by Fernando Cuadra in 1975, and another by Kurt Folch Mass, who published the play in Bogotá in 2002. It is interesting to notice that even though most Spanish editions

\footnotetext{
${ }^{1}$ The term was coined by F.S. Boas in Shakespeare and his Predecessors (USA: Greenwood Press, 1969).

${ }^{2}$ Juan Cariola, El mercader de Venecia (Santiago: Editorial Universitaria, 1998, $2^{\text {nd }}$ ed.).
} 
translate "wives" as "comadres" (neighbour, village woman), Folch chooses the literal "casadas" (married women) for his title. Finally, the group of Chilean Shakespeare comedies includes The Taming of the Shrew by Jorge Elliot in 1970, and a 2001 edition of the same play by Editorial Andrés Bello.

With respect to tragedies, the five translated in Chile are quite emblematic. They are major plays, whose popularity well represents their genre. Hamlet's first translated Chilean edition by José Bergua was published in 1944 together with Macbeth. Later, in 1976, Carmen Cienfuegos offered a single volume work including Hamlet, Macbeth, and King Lear printed by Editorial Andrés Bello. From then on, this printing house has published some of Shakespeare's works quite regularly in cheap format intended for schools, yet without explanatory notes. Once again, Juan Cariola's translation of Othello, Romeo and Juliet, and Hamlet was issued by Editorial Universitaria in 1982. His individual Hamlet appeared in bookstores in 1975 and reached its twelfth edition in 2011, as it is widely used for teaching not only at schools, but also at universities and Drama schools. In fact, Hamlet is the Shakespearean tragedy that has been most staged in the country, either by professional companies or by university groups. As most of Cariola's works, this version is written in prose and counts with some notes and illustrations. Curiously, there is an acknowledgement in the first pages to Dorothy Hayes who was a staff member of the British embassy, but we do not know anything about Cariola's relationship with her.

King Lear was first translated in the country by Carmen Cienfuegos in 1976 together with two other tragedies, but her version was never staged. ${ }^{3}$ Later, in 1992, the well-known Chilean poet, Nicanor Parra, translated the play for the successful production by the Theatre School of the Catholic University of Chile, directed by Alfredo Castro. Because of his literary achievements, surely including this translation, Parra was conferred the title of Honorary Fellow in 2002 at St. Catherine's College, University of Oxford, as one of its alumni. In 2004, Ediciones Universidad Diego Portales published his work: Lear rey y mendigo. Linguistically speaking, Parra's version is a remarkable translation since, according to Catherine Boyle, the antipoet was able to retain the structure of blank verse and to impose the meters of popular language on Shakespeare's formal meters. In this way, he "creates a language that is simultaneously recognizable and distant [...]" (Boyle 2005, p. 123), thus transfiguring

\footnotetext{
${ }^{3}$ Carmen Cienfuegos, Hamlet, Macbeth, Rey Lear (Santiago: Andrés Bello, 1976).
} 
Shakespeare's Lear into a Chilean Lear without losing the original rhythm, cadence, and musicality of Elizabethan English. Parra does not only incorporate Chilean idiomatic expressions in his version, but also transforms and recreates some aspects of the plot and the characters.

Three translations of Macbeth have been published in Chile. The aforementioned Bergua's edition of Hamlet and Macbeth from 1944, Cienfuegos's 1976 three tragedies, and Armando Roa Vial's edition published in 2001 in Bogotá. ${ }^{4}$ Othello has also been published by the same university printing press. This tragedy offers interesting information with respect to the Chilean canon. It was the first Shakespearean play staged in Chile by the year 1818. The tragedy was performed by a group of war prisoners in an old Jesuit house in Santiago where a provisional "National Theatre" was created and directed by Domingo Arteaga. ${ }^{5}$ More than a century later, Juan Cariola translated the play and Editorial Universitaria published it in a single volume that includes the tragedies of Othello and Romeo and Juliet. ${ }^{6}$ As usual, his translations count with some brief explanatory notes. In 2000, Norma editors published Jaime Collyer's translation of Othello in Bogotá.

The popularity of Romeo and Juliet seems to have crossed the Atlantic Ocean since it is one of the Chilean translations that has reached the highest number of editions together with Hamlet. In a fluent and poetic Spanish, Pablo Neruda, the acclaimed national poet and 1971 Nobel Laureate, published his version of the play in Buenos Aires in 1961, then in Barcelona in his Complete Works (2001-2002), and finally in Santiago (2010) which reached eight editions, long after the poet had died. In an interview Neruda gave in 1970 in Isla Negra - one of his residences - he declared that his translation had the value of presenting a humanized Shakespeare (Guibert 2001-2, p. 1143). Nevertheless, one of his friends and biographer, Volodia Teitelboim, reported some years later that he had commented to him how very complex translating Shakespeare had been; so much so, that he confessed he would not get involved again in the translation of another Shakespeare (Teitelboim 1985, p. 284; 339). Despite the poet's successful versions, Cariola becomes the leading translator of Romeo and Juliet

\footnotetext{
${ }^{4}$ Armando Roa Vial, La tragedia de Macbeth (Bogotá: Norma, 2001).

${ }^{5}$ Samuel Hais's account of the performance is registered in Mario Cánepa's El teatro en Chile, desde los indios hasta los teatros universitarios (Santiago, Chile: Arancibia Hnos, 1966), pp.46-47. The reference he makes is from: Luis Pradenas, Teatro en Chile: Huellas y trayectorias. Siglos XVI-XX (Santiago, Chile: Lom, 2006), p.141.

${ }^{6}$ See Cariola, Tres tragedias.
} 
in terms of numbers, since his individual work ${ }^{7}$, written in prose, with few notes and some illustrations, has been edited 18 times. The same play appears in his volume of three tragedies issued in 1981.

During Shakespeare's lifetime, the Elizabethan audience loved Histories. They could see their Kings and Queens represented onstage and debate about topical political and religious themes. Most of them, even those who had had no access to formal education, knew the history of England and could easily understand the complex plots - full of heroism, intrigue, patriotism, and treason - of these plays. Nevertheless, Histories are not the most popular Shakespearean works outside Britain since readers and theatregoers need a certain historical background to understand the plays in depth. Undoubtedly, a reader would be able to appreciate the story, the language, the characterization, and so forth without the need of historical antecedents, but when it comes to translating, perhaps writers and academics will not choose Histories very often. Usually, when these plays or the Roman plays have been translated or staged, at least in Latin America, they have been tinted with political colours. In 1959, Patricio Torres translated Richard II, which was published by Universidad Católica, one of the main and oldest universities in the country. Another national printing house, Editorial Andrés Bello, published Rojo's Richard III in 1999, written in prose, with prologue and introduction by the translator.

The list of Chilean translations comes to an end with the recent publication of The Tempest (2010) by Editorial Universitaria. Both translators, Baldwin and Fernández, are Literature lecturers who have been teaching Shakespeare for several years at university level. This is the only national translation that incorporates a critical introduction, indication of acts and scenes and number of lines in the page layout, as well as philological and historical notes. As it was already explained, Shakespeare's works are part of a collection where his works are aligned with literature Classics and great national and international authors. In a certain sense, these books are considered canonical due to its universal message and aesthetic value. In addition, this translation of The Tempest also shares with translations of Greek or Latin Classics - which belong to another collection - the presence of paratexts that explain parts of the plot, refer to translation issues, or inform about historical and cultural aspects that help reading comprehension.

\footnotetext{
${ }^{7}$ Juan Cariola, Romeo y Julieta (Santiago: Editorial Universitaria, 2010, $18^{\text {th }}$ edn.).
} 
Most of the aforementioned Chilean editions, as well as the Latin American, do not follow the academic standards for Shakespeare's publications currently used in the Anglo-Saxon world; that is to say, the majority hasn't got any kind of paratext or specific page layout (with line numbers, indication of acts and scenes) that usually facilitates the reading and study of works in verse. Besides, almost all of them are written in prose. In the case of the Spanish translations (from Spain) of Shakespeare's Complete Works that are more commonly read in the country at present, each of them adopts different editorial procedures: Instituto Shakespeare (Cátedra) individual translations, under the direction of Manuel Ángel Conejeros, offer bilingual editions that incorporate line numbers, notes, and abundant critical material, including bibliography and further readings. Luis Astrana Marín's translations include these paratexts only in his Obras Completas (1961), published by Aguilar, but not in individual copies of the plays. More recent Spanish translations, like those by ÁngelLuis Pujante (2008), offer abundant paratexts: a long introduction, some pictures and illustrations from performances of the plays, notes at the end of the publication, and indication of act and scene at the top of each page. He is also one of the very few translators who refer to the source text they used; that is to say, whether they translated from a 1623 Folio edition or from a Quarto. However, none of these authors indicate the modern edition the translator(s) worked with, nor do they include line numbers.

It is interesting to observe that most of the Chilean translations belong to the 1970s or later, except from one dating back to 1944 and another from 1959. In other words, most of these publications are very recent. The Shakespeare that has been traditionally read and staged in Chile is from Luis Astrana Marín's translations. However, the Chilean more cultivated social groups are likely to have read directly from English, or from French translations; probably, they have also had access to Spanish translations by Guillermo Macpherson. We also know that the first performances of plays by Shakespeare during the first half of the nineteenth century used translations from Teodoro de la Calle, who adapted French versions that Jean-François Ducis had done from Othello in 1792, and from Macbeth in 1784.

Almost every Chilean Shakespeare publisher is linked to a university press, theatre school, or academic printing house. It seems that Shakespeare's place in the Chilean canon is associated to higher education and culture. As we have pointed out, the fact that Editorial Universitaria includes Shakespeare in "The World of Letters" collection shows that he is considered to possess the same or even higher literary value 
than the authors listed in that series. If they have become authorities within the canon, then Shakespeare deserves to become an authority too. If reading the books of those writers has become a symbol of culture and knowledge, then reading Shakespeare will also become a source of wisdom. Nevertheless, how many Chileans read Shakespeare? The answer to this question is quite difficult to obtain. One thing is the canon that publishers intend to establish, and another, sometimes very different issue is what readers choose to read. A useful reference is that of the official figures for translations from English to Spanish in Chile. According to the Chilean Book Chamber institution that also regulates, grants, and registers the ISBN in the country - the total number of translations (that do not distinguish genre of the translated text) is as follows: 2005, 61; 2006, 63; 2008, 62; and 2009, 157. The average print run in Chile is of 1000 or 1500 copies per book. In addition to this, if we examine the list of Chilean translations, we can observe that most of them have not exceeded their first edition, except Neruda's Romeo and Juliet, Cariola's same play, and also his Hamlet, both published by Editorial Universitaria. However, if these numbers are multiplied by the many persons who read each copy of a book, in addition to the Shakespearean plays that are frequently staged by Drama schools, the final answer would be that some Chileans do read Shakespeare. We can assume that, if this were not the case, printing houses would not keep on publishing translations of his works into Spanish. Therefore, can we state that these translations form a Chilean Shakespeare canon? Is Shakespeare a literary authority exactly in the same way as he is in Britain?

\section{The Role of Editorial Universitaria and Juan Cariola Larraín in the Creation of the Chilean Shakespeare Canon}

Editorial Universitaria was founded in 1947 with the support of the University of Chile and private shareholders. It soon became one of the most prestigious Chilean university presses, and also one of the most important in South America during the decades between 1960 and 1970. Its ethos is grounded in the idea of editing and disseminating cultural, academic, and educational topics through the publication of books in order to serve the Chilean universities and its society as a whole. ${ }^{8}$ It has dedicated itself for more than half a century to the publication of the most selected authors of the national intellectual world, in topics related to Philosophy, Sciences and the Humanities. Its catalogue is of great value not only because of the number of titles it

\footnotetext{
${ }^{8}$ History of Editorial Universitaria is available at http://www.universitaria.cl
} 
offers (more than 1000), but also, and mainly, for the literary reputation of its authors, among whom there are Nobel Prizes, Literature National prizes, and most of the Science, History and Art local prizes as well.

A press belonging to the University of Chile, Universitaria adds to its own publications of Shakespeare those that it has published for the university's Theatre School, thus becoming the publisher that has printed the highest number of Shakespeares in the country. Besides, Parra and Neruda were lecturers at that university and published their King Lear and Romeo and Juliet, respectively, in Universitaria. This printing house has also published translations of other British writers, such as, among others: anonymous Anglo-Saxon poets, Robert Browning, R. L. Stevenson, Oscar Wilde, D.H. Lawrence, T.S. Eliot, Ezra Pound, and C.S. Lewis. This shows that even though Universitaria's interest for Shakespeare translations is manifest in the number of plays printed, it also assigns value to British literature beyond Shakespeare.

Undoubtedly, one of the leading Chilean translators was Juan Cariola Larraín. Although he died many years ago, his translations are still used for teaching and performance, and have reached a considerable number of editions. We know very little about him, so much so that Nicanor Parra, impressed after reading his Hamlet, tried to find out who this man was without much success. He tells this in an interview he gave to Revista Paula in 1998 where he stated that Cariola's Hamlet was the best translation of the tragedy he had ever read and that he considered its author an erudite anonymous hero. He looked for his name in the directory and rang to the telephone he found under his surname. To his surprise, the lady who answered the phone was Cariola's sister who told the antipoet that her brother had died and that she did not know much about his works (Donoso 1998). Driven by curiosity and determined not to give up until I found more information about this great Chilean translator, I rang the Editor General of Universitaria hoping that he could give me more details. He remembered that Cariola was a teacher and that he was a very kind man. He also gave me the email of one of Cariola's sons-in-law to whom I wrote immediately. The following week I was invited to a meeting with Cariola's eldest son, Jorge, with one of his daughters, Carmen, and with Osvaldo Sunkel, her husband, at the Cariolas' flat. They spoke of him with love and admiration. Born on the $21^{\text {st }}$ of August, 1903, he worked as a teacher of English for at least 35 years, thus being granted a special recognition by the government for his service to the development of Chilean education. He used to teach in public schools, yet examined pupils from private institutions. He loved English literature and usually spent 
the nights translating his favourite authors or writing his own poems and short stories. To my amazement, his son brought to the meeting a tiny suitcase with all his father's works - handwritten or typed in separate sheets of paper or small copybooks of different sizes (all of them with yellowed sheets). Among these, I found not only drafts of all his published works, but also unpublished translations of Shakespeare's plays such as The Tempest, Troilus and Cressida, and at least 46 of the playwright's Sonnets. Even though this narration might seem like a detective story rather than academic evidence, it could result in the editing and publication of more "Chilean Shakespeares", thus not only making the national canon increase in number, but in variety, and, certainly in quality, as Cariola's pen is really well-crafted. He died at the age of 78, on August $19^{\text {th }}$ of 1981 , leaving behind a great legacy to the literature and culture of his country.

Although we have already mentioned some characteristics of Cariola's translations, it might be useful to enumerate all of them in order to find evidence that might explain the success of his versions. First of all, his translations are written in prose and are usually very faithful to the original sense of the text. His rich, varied, and fluent language makes Shakespeare sound very well in Spanish. He generally sticks to the playwright's rhythm, to some of his phrasing, and recreates many of his puns; sometimes he is also able to stress verb tenses in a similar way as it was done in Elizabethan English. With respect to the edition of his translations, they have got an elemental but valuable critical apparatus, with few notes to the text, yet relevant to the better comprehension of the plot. Sometimes a prologue and a basic but thorough introduction are incorporated. These paratexts are usually written for students, not for experts. In some cases Fernando Debesa, national playwright, wrote the prologue. Acts and scenes are not indicated in each page, but only at the beginning of each section; there are no numbers either for lines or verses. There is no bibliography or information of the text or edition used, although in the case of Hamlet, for example, it is likely that Cariola might have translated Q2, yet we do not know from which modern edition he took it. Some of his editions include illustrations (for example, by Marta Carrasco in Hamlet; Nelson Guajardo in Romeo and Juliet; Iván Serrano and Pablo Martínez for Tres Comedias), perhaps to make them more attractive for school students. The books are printed in pocket format $(11.5 \times 18.2 \mathrm{~cm})$ and are paperback editions with Baskerville 10/11 typography; Linotron 202 Melior, a font that is quite easy to read. The price of these books fluctuates from 7 to 10 US dollars. 


\section{Chilean Shakespeare and its Paratexts: The Case of The Tempest}

The Chilean translation of The Tempest, from the 1623 Folio text as presented in the Vaughans Arden $3^{\text {rd }}$ Series edition of 1999 (reprinted in 2006), is the first national translation that incorporates division of acts, scenes and line numbers in the page layout according to the academic standards currently in use for Shakespeare editions in the Anglo-Saxon editorial world. This means, that any reader in any country of the world can identify the same text by its act, scene and line very easily. In addition, it includes a number of paratexts such as an introduction that is divided in several sections: historical background (London ca. 1600); composition and sources of the play; The Tempest's nature and genre; Shakespeare's style, and a brief description of the translation methodology. The text is also accompanied with different types of notes: some attempt to illuminate certain obscure passages; others define the sense of some words and expressions that have been debated over the years or that are no longer used in modern English; a good number of them explain puns that were not always possible to reproduce, and few bring to discussion some debates that do not necessarily appeal to the common reader, yet are interesting for the experts.

Notwithstanding that the presence of paratexts could sometimes force the reader to focus on specific elements of the text or influence his interpretation of it, the purpose of paratexts in this translation is to offer the reader the access to linguistic, historical, and cultural information that may facilitate his reception and understanding of the play. As Gerard Genette states, "more than a boundary or a sealed border, the paratext is rather a threshold, or - a word Borges used apropos of a preface - a "vestibule" that offers the world at large the possibility of either stepping inside or turning back" (1997, p. 1). In other words, readers can take advantage of them when they need contextual or extra textual elements for a more pertinent reading. Paratexts in this translation are an invitation, not an imposition, yet considering that Shakespeare's plays were written more than 400 years ago within a distant and different cultural background, and in an English that might be alien even to native speakers today, paratexts can certainly become a compass to "travel" across the translated text.

In addition to the Vaughan's text of the play, in some cases the translators used this edition's notes and philological repertoire. For lexical variations and complementary information in linguistic, theatrical, and historical discussions, they also worked with Stephen Orgel's version (Oxford, 2008), and David Lindley's work (Cambridge, 2002). It was also useful to look at classic editions from J.R. Sutherland 
(Oxford, 1939/1958) and A.W. Verity (Cambridge, 1954), which many times shed light to understand difficult passages or expressions. Baldwin and Fernández also looked at Spanish versions by Luis Astrana Marín (Aguilar, 1951), José María Valverde (Planeta, 1968), Ángel-Luis Pujante (Espasa Calpe, 1999), Shakespeare Institute (Cátedra, 2005) and Pablo Ingberg from Argentina (Losada, 2005), so as to analyse the way in which they solved syntactic and semantic issues. The list of translations used during the process of study demonstrates that translating is not only a linguistic process, but also a literary and intellectual one in which many social and cultural agents participate. In terms of the book market, it means that in a certain sense each translation of a play is a recreation of the original in another language, and at the same time it is a revision of previous translations that constitute a linguistic tradition or history of that play. Understood in this way, translations may contribute to maintain certain books within the literary canon of each country since they keep on being rewritten, and consequently printed and published. Translations also widen the scope of the local canons as they open up the possibility of reading foreign authors in the peoples' native language. Certainly, to translate never becomes an isolated process; the person who translates transforms and is transformed. In this sense, the Chilean Tempest is part of an endeavour that transcends the authors' individual work.

The translation methodology that Baldwin and Fernández adopted does not constitute a complex and sophisticated model. The method consisted of five stages or steps: a deep period of study of the play; long discussion sessions to establish a common interpretation (understanding each character, his relationships and his dramatic conflicts well). Then, the authors translated the chosen edition line by line in a bilingual document and after that, they made dozens of readings and revisions of the translated material. Finally, some work sessions were devoted to reading the final Spanish version aloud. This was the best examination of the work done as it allowed the translators to check the text's fluency, musicality and rhythm.

We could say, without taking pride in the achievement at all, that The Tempest has inaugurated a different approach to translation and editing Shakespeare's plays in Chile. It took some distance from the traditional translation and printing approaches in our language: recreation in prose or translation into a metrical structure equivalent to blank verse. The genius of Shakespeare is expressed in the perfect unity between form and matter, metre and theme. Therefore, for those of us who cultivate another language translating Shakespeare becomes a real challenge. The fact that the work of Shakespeare 
is what he wrote, exactly as he did, with a highly poetic and creative way of using Elizabethan English confirms that, if in strict sense every translation is impossible, with Shakespeare this is so in a superlative sense. Considering the nature and characteristics of blank verse and Shakespeare's talent using it, it is not possible to reproduce it exactly in Spanish. We are left with the option - followed by other translators - of putting it in prose or transferring it into a metrical system more or less equivalent in Spanish, saving in this way its formal dimension. But this alternative presents serious problems: any Spanish structure that could be chosen, will permanently run the risk of losing the sense of the verses and, in many cases, it will mutilate what is said or at least will transform the text into a somewhat rigid structure, thus weakening its vitality onstage.

The translators chose an intermediate path. They kept the lines and the original cuts in the passages in prose and verse, although not fitting the latter into any Spanish metrical system. Moreover, they kept the Shakespearean over-flow for the lines and their subsequent numeration. They focused their effort in preserving the strict sense of those lines, their syntax (a very complex aspect), and in adapting the pauses and rhythm resulting from the original punctuation to the possibilities that Spanish punctuation offers. This allowed them, together with the lyrical tone they intended to give to the verses, to reasonably maintain the differences and inflexions that the playwright wanted to give to his characters' utterances.

Whenever it was possible they reproduced the intentional repetition of words and even the cacophony of the original text, as well as the idiomatic expressions, verb tenses, the vitality of elisions, and specific contractions that were possible to recreate in our language without adding rigidity to its prosody. Analogous criteria were followed regarding articles, prepositions, use of dashes, parenthesis; almost all of them were kept. It was not the case of syllable omissions and compound words because they have no equivalent in Spanish.

The translators were especially careful to keep the Elizabethan formal voice you and the informal thou, even in those speeches in which Shakespeare changes indistinctively from one to the other; they transferred it to the common Spanish that is used today in almost every country in Latin America: usted and tú, respectively. With respect to stage directions, they followed those established by the Vaughans, considering the continuing development of these paratexts throughout the textual history of the play (Jowett 1983). 
We include here two examples - first in English and then in the translated Spanish version - where we can observe some of the aforementioned linguistic and stylistic features. The first speech, spoken by Prospero, shows some characteristic elements of Shakespeare's poetics like, for example, the repetition of pronouns (thee, I) that usually make the reader/audience focus their attention on a specific character.

\section{PROSPERO No harm! \\ I have done nothing but in care of thee, \\ Of thee, my dear one, thee my daughter, who \\ Art ignorant of what thou art, naught knowing \\ Of whence I am, nor that I am more better \\ Than Prospero, master of a full poor cell, \\ And thy no greater father.}

(The Tempest, 1.2.15-21, emphasis mine)

Baldwin and Fernández respected line numbers and the text's original cuts. They attempted to repeat pronouns as Shakespeare did, but it was not always possible without losing some of the original language's fluency, rhythm and musicality. In addition, the personal pronoun "I" is very rarely written at the beginning of a sentence in Spanish; it is often a tacit or unspoken subject and as such it can neither be visually reproduced nor contribute to the number of syllables in a line.

\section{PRÓSPERO}

No he hecho más que cuidarte

¡Ningún mal!

A ti, mi amada hija, a ti; que,

Ignorante de lo que eres, tampoco sabes

De dónde vengo ni que soy bastante más

Que Próspero, el amo de esta pobre gruta,

Tu humilde padre.

(La tempestad, 1.2.15-21)

Another example, taken from one of Caliban's speeches, shows another dilemma the translators had to solve:

\section{CALIBAN}

Be not afeard. The isle is full of noises,

Sounds and sweet airs that give delight and hurt not.

Sometimes a thousand twangling instruments

Will hum about mine ears; and sometime voices,

That if I then had waked after long sleep, 
Will make me sleep again; and then in dreaming,

The clouds, methought, would open and show riches

Ready to drop upon me, that when I waked

I cried to dream again.

(The Tempest, 3.2.135-43)

\section{CALIBÁN}

No temas; la isla está llena de ruidos,

Sonidos y brisas dulces que deleitan y no hacen daño.

A veces, un millar de instrumentos vibrantes

Resuena en mis oídos. Y otras, son voces

Que si acabo de despertar de un largo sueño,

Logran dormirme de nuevo. Y entonces, soñando,

Veo que las nubes se abren y muestran riquezas

Que van a derramarse sobre mí... Cuando despierto,

Lloro por soñar otra vez.

(La tempestad, 3.2.135-43)

These verses illustrate the fact that quite often a Spanish translation cannot reproduce the onomatopeic sounds of poetic English language (i.e: the sound of the "s" in noises, sounds, sweet, and sometimes, that imitates or conveys the idea of a fair breeze, is not achieved in the same way in Spanish because the translated words do not share the same phoneme: 's'). Regarding repetition of words, the English version repeats "sleep", but first it is used as a noun and then as a verb. In Spanish, we could translate 'long sleep' as 'largo dormir' (where "dormir" is used as a noun), and then repeat "dormir" as a verb, in the next line; however, when Caliban says that voices 'will make me sleep again', the Spanish syntax will transform that verbal expression into a reflexive verb: 'dormirme' and thus the repetition "sleep/sleep" translated as "dormir/dormir" will not work in Spanish. Besides, the translation of "long sleep" as "largo dormir" will not be as poetic as 'largo sueño'; it will definetily not convey the same meaning. Spanish, thus, needs two different words to express what the character wants to say.

After the publication of the first Chilean Tempest, Editorial Universitaria has decided to follow the system of indicating act, scene and line number in each page as an editorial policy for the coming publications of Shakespeare's plays, thus providing evidence that in spite of the language barrier, there may be means and methods that facilitate reading translations better. In fact, one of the main goals of Baldwin's and Fernández's work was to contribute to the academic work in countries where English is not the mother tongue; in other words, to make the play functional to the common 
reader. This objective was especially inspired in the hope of recovering Shakespeare for the theatre of our countries; a wish that will be fulfilled in time and thanks to the effort of the always "happy few" (Henry V, 4.3.60).

\section{Conclusions}

It is undeniable that Shakespeare has become global. He is read and staged all over the world in his original Elizabethan English, as well as in adaptations and translations into almost every existing language. Reading Shakespeare is part of a universal culture, and in certain academic and social groups, knowing his works adds to one's cultural and social status.

His plays have survived not only because of their literary quality, but also because they imitate human actions. Perhaps this is the strangeness Bloom refers to when it comes to decide whether a work is canonical or not. As readers, we feel identified with his characters because we recognise in them human traits, virtues, and visible faults. He speaks of truths that are still human abiding concerns.

Like most publishing houses, Editorial Universitaria is a business company that needs to sell books in order to survive in the book market. Nevertheless, the authors and titles that are included in its catalogue reveal that it has a true interest in the transmission of art and culture. If their policy throughout the years has been to publish Shakespeare translations it may be either because Shakespeare is a profitable cultural product in Chile, or because editors appreciate his literary value and possible contribution to the cultural development of the country. I would say that the publication of Shakespeare translations shows both selling strategies at the same time and in different degrees; in other words, that in the printing business there are always commercial and cultural elements combined. Little by little, the playwright's works are being incorporated into schools' curricula and his study is part of undergraduate and graduate Literature programmes. There is still much effort to do so that Shakespeare enters into every public classroom in the country, yet the fact that his plays are being performed more often by professional and amateur actors, as well as students, undoubtedly contributes to create an interest in reading his books, either in English or in Spanish. The Tempest is an example of this phenomenon since it was published in September 2010 and it was staged in October 2011 by students from the Academy of Visual Arts from Universidad de los Andes in Santiago. 
We hope that more Shakespeares will be translated and printed in the country so that the Chilean Shakespeare canon will increase not only in numbers, but in linguistic and editing quality. With respect to the latter, issues such as book design, page layout, type of paper, and inclusion of good paratexts, when necessary, show that not only size matters to make a difference - as in the case of the 1623 Folio — but page layout and paratext. These elements have an impact in terms of facilitating the reading of a play, but also when taking decisions regarding editorial policies which move the book market in terms of circulation of copies, as well as supply and demand of books. If Shakespeare has become part of the Chilean literary canon, it is because it has been made available in Spanish by the joint effort of Spanish and Chilean translators and publishers who have taken the challenge and have printed his works.

\section{References}

ASTRANA MARÍN, Luis. Obras Completas de William Shakespeare. Estudio preliminar, traducción y notas. Madrid: Aguilar, 1961, $13^{\text {th }}$ edn.

BALDWIN LIND, Paula; FERNÁNDEZ BIGGS, Braulio. La tempestad. Introducción, traducción y notas. Santiago de Chile: Editorial Universitaria, 2010, $1^{\text {st }}$ edn.

BERGUA, José. Hamlet, Macbeth. Santiago: Zig-Zag, 1944.

BLOOM, Harold. The Western Canon: The Books and School of the Age. New York, San Diego, and London: Harcourt Brace Company, 1994.

BOAS, Frederick Samuel. Shakespeare and his Predecessors. USA: Greenwood Press, 1969.

BOYLE, Catherine. Nicanor Parra's Transcription of King Lear: The Transfiguration of the Literary Composition. In: KLIMAN, Bernice W.; SANTOS, Rick J. Latin American Shakespeares. Madison, N.J.: Farleigh Dickinson University Press, 2005, p. 112-129.

CÁNEPA, Mario. El teatro en Chile, desde los indios hasta los teatros universitarios. Santiago, Chile: Arancibia Hnos, 1966.

CARIOLA, Juan. Hamlet, Príncipe de Dinamarca. Santiago: Editorial Universitaria, $1^{\text {st }}$ edn, 1975; $12^{\text {th }}$ edn., 2011.

El mercader de Venecia. Santiago: Editorial Universitaria, 1998, $2^{\text {nd }}$ edn.

Romeo y Julieta. Santiago: Editorial Universitaria, 2010, $18^{\text {th }}$ edn. 
Tres comedias: El mercader de Venecia, Sueño de una noche de verano, Como gustéis. Translation and notes by Juan Cariola; Prologue by Fernando Debesa. Santiago: Editorial Universitaria, 1981, $1^{\text {st }}$ edn.

. Tres tragedias: Otelo, Romeo y Julieta, Hamlet. Traducción y notas. Santiago: Editorial Universitaria, 1982, $1^{\text {st }} \mathrm{edn}$.

CUADRA, Fernando. Las alegres comadres de Windsor. Santiago: Universidad de Chile, Servicio de Publicaciones Escuela de Teatro, 1975.

CIENFUEGOS, Carmen. Hamlet, Macbeth, Rey Lear. Santiago: Andrés Bello, 1976.

COLLYER, Jaime. Otelo, el moro de Venecia. Santa Fe de Bogotá: Norma, 2000.

DONOSO, Claudia. "Nicanor Parra revisitado." Revista Paula. Santiago: Noviembre, 1998.

ELLIOTT, Jorge. La fierecilla domada: Comedia en cinco actos. Santiago: Universidad de Chile, Servicio de Publicaciones Escuela de Teatro, 1970.

ERNE, Lukas. Shakespeare as Literary Dramatist. Cambridge: Cambridge University Press, 2003.

FOLCH MASS, Kurt. Las alegres casadas de Windsor. Bogotá: Norma, 2002.

GENETTE, Gerard. Paratexts: Thresholds of Interpretation. Trans. Jane E. Lewin Cambridge: Cambridge University Press, 1997.

GREG, W.W. The Shakespeare First Folio. Its Bibliographical and Textual History. Oxford: Clarendon Press, 1955.

GUIBERT, Rita. "Conversaciones frente al océano". In: NERUDA, Pablo. Obras Completas, Barcelona: Galaxia Gutenberg S.A., vol. 4, 2001-2002.

HINMAN, Charlton. The Printing and Proof Reading of the First Folio of Shakespeare. Oxford: Oxford University Press, 1963.

JOWETT, John. The First Folio. Shakespeare and Text. Oxford Shakespeare Topics.

Oxford: Oxford University Press, 2007, p. 69-92. . New Created Creatures: Ralph Crane and the Stage Directions in The Tempest. Shakespeare Survey 36 (1983), p.107-120.

KLIMAN, Bernice W. and Rick J. Santos (Eds.). Latin American Shakespeares. Madison, N.J.: Farleigh Dickinson University Press, 2005.

LETELIER, Hernán. El mercader de Venecia. Santiago: Universidad de Chile, Servicio de Publicaciones Escuela de Teatro, 1978.

NERUDA, Pablo. Romeo y Julieta. Buenos Aires: Losada, 1961. Obras Completas. Barcelona: Galaxia Gutenberg S.A., vol. 4, 2001- 2002. 
Romeo y Julieta, $8^{\text {th }}$ edn. Santiago: Pehuén Editores, 2010.

ORTHOUS, Pedro and Jaime Silva. Comedia de equivocaciones. Santiago: Universidad de Chile, Servicio de Publicaciones Escuela de Teatro, 1967.

PARRA, Nicanor. Lear rey y mendigo, ed. Alejandro Zambra. Santiago: Ediciones Universidad Diego Portales, 2004.

POLLARD, A. W. Shakespeare Folios and Quartos: A Study in the Bibliography of Shakespeare's Plays 1594-1685. London: Methuen, 1909.

PRADENAS, Luis. Teatro en Chile: Huellas y trayectorias. Siglos XVI-XX. Santiago, Chile: Lom, 2006.

PUJANTE, Ángel- Luis y Salvador Oliva. William Shakespeare: Teatro Selecto. 2 vols. Madrid: Espasa Calpe, 2008.

RASMUSSEN, Eric. Folios. In: DOBSON, Michael; WELLS, Stanley. The Oxford Companion to Shakespeare. Oxford: Oxford University Press, 2001.

ROA VIAL, Armando. La tragedia de Macbeth. Bogotá: Norma, 2001.

ROJO, Rodolfo. Ricardo III. Santiago: Editorial Andrés Bello, 1999.

STUARDO, Oscar. Sueño de una noche de verano. Santiago: Universidad de Chile, Servicio de Publicaciones Escuela de Teatro, 1979.

SHAKESPEARE, William. The Tempest. Edited by Virginia Mason Vaughan \& Alden

T. Vaughan. The Arden Shakespeare, $3^{\text {rd }}$ Series. London: Thomson Learning, 2006. TEITELBOIM, Volodia. Neruda. Buenos Aires: Losada, 1985.

TORRES HENRÍQUEZ, Patricio. Ricardo II. Santiago: Editorial Universidad Católica, 1959. 